\section{Forestry Policy Developments} Timber/Wildlife \section{Management in Alberta}

The introduction of wild life management into the management of timber production forests has been an objective of many land management organizations throughout the world for some time. Most foresters recognize wildlife as part of the forest scene and many take enjoyment in recreational benefits involving wildlife and fish in the forest setting.

In Alberta, this desire became action in 1977 in the form of a policy initiative by the provincial government document, "A Policy for Resource Management of the Eastern Slopes", or commonly referred to as the "Eastern Slopes Policy". This policy document formalized the multiple use philosophy for management for watershed protection, timber production, recreation, fish and wildlife protection, domestic grazing and mineral production.

In April, 1982, a workshop entitled "Timber Harvesting in the Boreal Forest Capitalizing for Wildlife" was co-hosted by the Alberta Forest Service and the Fish and Wildlife Division of the Department of Energy and Natural Resources, in Jasper, Alberta. The objective of the workshop was to bring foresters and wildlife biologists, from both government and industry. together to discuss and recommend resolution to the integration of wildlife and timber management objectives.

The key note speaker to the workshop, Dr. Jack Ward Thomas, Chief Wildlife Biologist, Range and Wildlife Habitat Laboratory, US Forest Service, Portland, Oregon, provided a most inspiring presentation of an integration process for timber and wildlife management which he had worked to develop for an area called the Blue Mountains in northeastern Oregon and southwestern Washington. He pointed out that in most managed forests, the dominant land management activity is timber management. Large scale wildlife management usually results from the manipulation of forest vegetation primarily for wood production. In his words, "timber management IS wildlife management".

The essence of Dr. Thomas' approach to integration rests with identifying the habitat requirements of various species of wildlife and relating these requirements to the plant community successions, which follow as a result of harvesting and reforestation of forest under wood production management. Dr. Thomas was quick to point out that his "approach" or procedure would in itself not result in an integrated timber/wildlife management plan, but it would provide the answers, in quantifiable form, of the impact of specific wildlife species at the various stages of forest plant succession.

At the conclusion of the Jasper workshop, St. Regis (Alberta) Limited, a major forest management agreement holder located in westcentral Alberta, offered to join the provincial Fish and Wildlife Div- ision and the Alberta Forest Service an integrated forest/ wildlife management plan approach for Alberta using their forest management area as the pilot area.

Shortly afterwards, a task force was established at the instance of Alberta Energy and Natural Resources to prepare an integrated plan for the St. Regis forest management area. The nine-member committee is made up of three members each from St. Regis, the Fish and Wildlife Division and the Alberta Forest Service. The committee hopes to complete its report before the end of 1984 .

\section{Canada/Alberta Forest Resource Agreement Signed}

The Canada/Alberta Forest Resource Development Agreement was signed on October 26 by the Honourable Gerald S. Merrithew, Minister of State (Forestry) and the Honourable John Zaozirny. Minister of Alberta Energy and Resources. Under its terms, each government will spend $\$ 11.5$ million during the next five years to develop Alberta's forest resources and forest industry.

Activities under the agreement are grouped into three program areas: refores tation (\$7.4 million); applied research, technology transfer and opportunity identification ( $\$ 14.5$ million); and public information, evaluation and administration (\$1.1 million)

Reforestation Potentially productive forest land has remained unregenerated for years after fire or other disturbances. Federal efforts under this program will be devoted to federal Crown land, while provincial efforts will be concentrated on burned acres in northern Alberta.

Applied Research, etc. Research will concentrate on forest product development, particularly new and better uses for Alberta's extensive stands of aspen and poplar ( $\$ 10$ million); and developing better forest management, especially in newly forested areas $\$ 4.5$ million). Emphasis will be prompt transmission of research results from scientists to field foresters.

Public Information A public information program will be developed to assist Albertans in becoming more knowledgeable about forestry programs and opportunities. The agreement will be managed by a directorate consisting of Al Brennan, assistant deputy minister, Alberta Energy and Natural Resources, and Dave Kiil, regional director of the Canadian Forestry Service.

\section{Ontario Forestry Council Established}

On October 29, Ontario Minister of Natural Resources Alan Pope announced the establishment of an Ontario Forestry Council to recommend priorities and funding for forest research in the province. The chairman of the Council is Bernd Koken, President and Chief Operating Officer. Abitibi-Price Inc. Other members are: Edward F. Boswell, Senior Vice Président, E.B. Eddy Forest Products Ltd.; Charles J Carter, Chairman of the Board and President, Great Lakes Forest Products; John E. Houghton, President and Chief Executive officer, Ontario Paper Company; Michae Willick, Forester, Liskeard Lumber; James Cayford, Director, Great Lakes Forest Research Centre; and Dr. Robert G. Rosehart, President, Lakehead University.

Mr. Pope hopes that the Council will promote partnership between industry and government in research and forest management. In a letter to Mr. Clark, President of the CIF, however, he said that the Council will in no way usurp the function of the Canada-Ontario Joint Forest Research Committee, which is concerned with the activities and $R$ \& D programs of the CFS and the Ontario Ministry.

\section{The Annual Meeting Schedule}
1984 - August 5-9, Quebec City, Quebec Theme: "Forest Resources Management - The Influence of Policy and Law" This is a joint meeting of l'Ordre des ingénieurs fore- stiers du Québec, the Society of American Foresters and the International Union of Societies of Foresters, of which the Canadian Institute of Forestry is a member.
1985 - September 22-26, Winnipeg, Manitoba Theme: The Forest - Who Manages?
1986 - September 22-25, Victoria, B.C. Theme: The Man Made Forest - What is it? Who needs it?

1987 - August 3-6, St. John's, Nfld. 